\title{
Influence of MIS components on efficiency of e-marketing strategies: Evidence from telecommu- nication organizations in Jordan
}

\author{
Fadwa Issa Ahmad Alsalima*
}

\begin{abstract}
${ }^{a}$ Department of Computer Science, The Applied College, Imam Abdulrahman Bin Faisal University, Dammam, Saudi Arabia C H R O N I C L E

\section{A B S T R A C T}

Article history:

Received: June 18, 2021

Received in revised format: July

29,2021

Accepted: September 25, 2021

Available online: September 25 2021

Keywords:

Management Information Systems

Executive Support Systems

Marketing and Sales Information

System

E-Marketing

Market Share

The study aimed to highlight the role of management information system (MIS) and its components in improving the effectiveness and efficiency of e-marketing strategies in telecommunications companies in Jordan. By relying on the quantitative methodology and by dealing with the questionnaire as a research tool, 131 individuals from the marketing departments in the organizations under study responded, and after the analysis, the study demonstrated an impact of MIS and its components on e-marketing strategies by influencing how and the mechanism of data processing and presentation as information that contributes to making the most appropriate marketing decision. The study also proved that all components of MIS have an impact on e-marketing strategies, most of which were "human resources" or people, which proved that the efficiency of individuals and their ability to deal with technology carries significant effect on the effectiveness of MIS in managing and organizing emarketing strategies. The study recommends the necessity to focus on human resources with STEM skills, namely science, technology, engineering, and mathematics in order to ensure the best outcomes of MIS.
\end{abstract}

Competitiveness

C 2022 by the authors; licensee Growing Science, Canada.

\section{Introduction}

Nowadays, the concept of information and its organization has become an integral part of the organizations that rely on it to organize its internal and external operations, in addition to improving the outputs of implementing their strategies and organizing their relationship with clients (Lin \& Chiang, 2016). According to Altmann and Linder (2019), with the continuous development of the foundations for dealing with information and updating the systems of exploration and dealing with this information, which kept pace with the great momentum of information and the development of the Internet and the technology related to it, organizations are required to adopt more organized and stable foundations in order to manage their information in the way it becomes this information more useful to it, which led to the emergence of what is called Management Information Systems or MIS (Martell, 2018). Both Ali (2019) and Yordanova (2018) also indicated that IT plays a prominent role in the internal and external operations of organizations that depend on information technology, as it greatly contributes to supporting the different managerial processes according to various foundations and standards for each department. In general, and as indicated by Meeßen (2019), the concept of the system starts from its definition as a set of elements and components between which a lot of interactions occur to achieve a specific goal. As for information, the organization receives or collects the raw data and later transforms (processes) it from data to information. This transformation comes from the various organizational, managerial and decision-making processes that take place within the organization and that they carry out by relying on many tools, plans and strategies, including MIS as confirmed by Singh (2017).

* Corresponding author.

E-mail address: fialsalim@iau.edu.sa (F. I. A. Alsalim)

(C) 2022 by the authors; licensee Growing Science, Canada. doi: $10.5267 /$ j.ijdns.2021.9.015 
From this standpoint, we can say that information systems are the sum of the procedures that the organization undertakes to process, store and retrieve data for the management, which will help departments in making decisions according to managerial levels. Marketing is one of the operations that an organization undertakes to promote its services/products, attract customers, and preserve its share of the market. With the marketing strategies, the organization receives a huge bulk of data that it needs to transform it into usable information to make decisions and make the necessary calls for certain situations, conditions or even avoid certain risks (Chiang et al., 2018). With the development of internet, and the appearance of e-marketing as an approach to market and promote services and products; organizations realized the size of data that it gets from e-marketing and began to take extraordinary measures to screen and process data pouring from e-marketing means and tools (Lui \& Au, 2017). Based on the above argument, the current study seeks to examine the influence of MIS dimensions (Devices, Programs, Processes, Data and People) on the success and efficiency of e-marketing strategies. Fig. 1 highlights the relationship between study independent and dependent variables as according to previously presented aim:

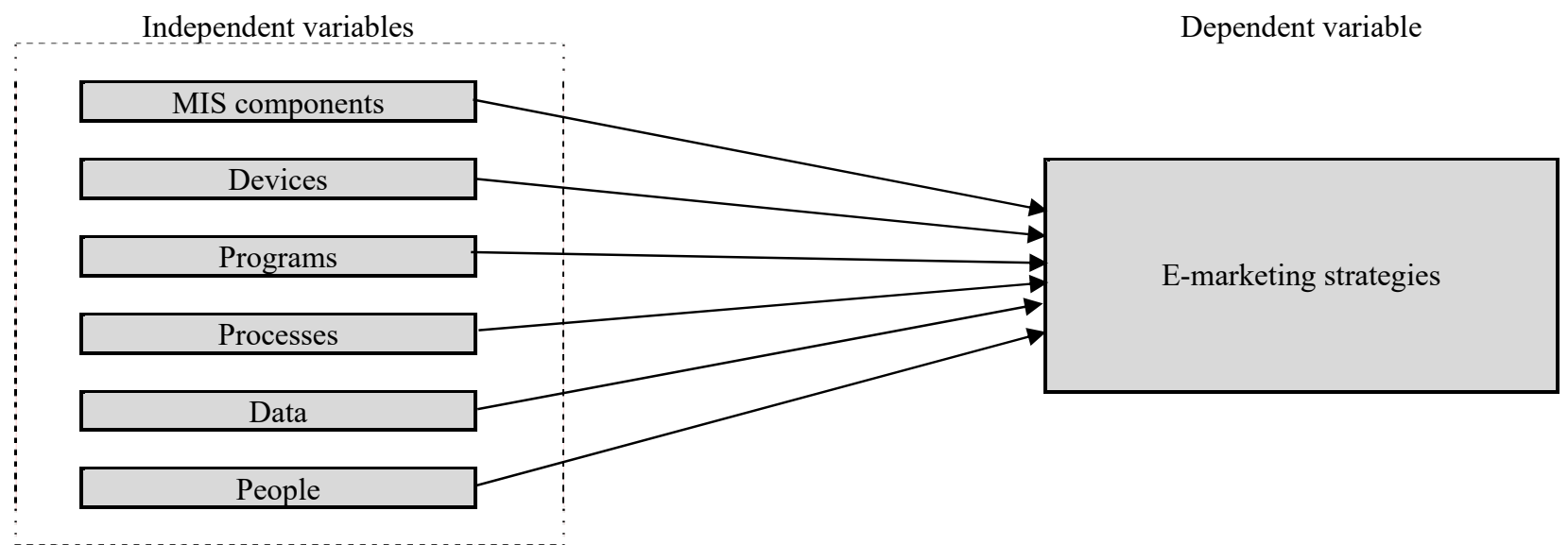

Fig. 1. The structure of the proposed study

\section{Hypothesis development}

According to Freihat (2012) information systems have provided a lot of aid to marketing strategies by giving the organization the ability to deal with big data, especially in the case of e-marketing. The researcher believes that information systems in all their forms have been able to contribute significantly to facilitating and automating the process of organizing data and converting it from data into organized information that can be used by the organization. This matter greatly contributed to activating the ability of departments to make marketing decisions, and organizational decisions in the event of risks, right up to the stage of creating what is known today as Marketing Information Systems. From another point of view, Quesada-Pineda et al. (2017) stated that information systems have replaced the old traditional systems, especially in the field of marketing, marketing management and directed marketing through the possibility of providing information after it was data, and this matter was through the hardware and software (devices and programs) that the organization adopted to deal with the raw data that results from e-marketing operations. While Albuquerque et al. (2018) emphasized that hardware, software (devices and programs), processes and the method of use, in addition to the users (people), contributed to providing a framework linking marketing operations with information systems services based on the marketing management that facilitates the search for new applications and opportunities to redesign marketing operations and other managerial processes in a manner that is more innovative using modern information technology. Vyas et al. (2014) stated that the concept of MIS in the marketing field is crucial in defining how IT is employed in that field. Authors stated that with MIS involved in marketing operations within an organization; there would be a chance to monitor the market and identify the market sectors that are changing constantly which gives the organization the ability to adapt to such changes and alter its marketing strategies in a way that suits the new market. Aditya (2014) agreed with what came along with Vyas et al. (2014) stating that not only MIS applications and components help in monitoring the market, it also help in developing marketing strategies and formulae strategies that are suitable to targeted audience in accordance with environment, nature of product/service and the level of competitiveness in the field of marketing. On the same track, Goel and Tiwari (2020) saw in management information systems along with its components an approach for the organization to achieve functional integration; this concept can be achieved through MIS when an organization depend on well-built MIS infrastructure where valid interaction is vivid between its devices, programs, users, processes, and data. This interaction can help in coordinating the activities of the marketing department with other departments. Based on allegations of previous studies, following set of hypotheses were developed by researcher in accordance with previous studies and study model presented earlier:

\section{Main Hypothesis}

H: MIS components positively influence e-marketing strategies. 
Sub-Hypotheses:
H1: Devices positively influence e-marketing strategies.
$\mathbf{H}_{2}$ : Programs positively influence e-marketing strategies.
$\mathbf{H}_{3}$ : Processes positively influence e-marketing strategies.
H4: Data positively influences e-marketing strategies.
H5: People positively influence e-marketing strategies.

\section{Literature Review}

\subsection{Management Information System (MIS)}

Trivedi and Verma (2018) defined management information systems (MIS) as a set of computerized systems introduced to serve the higher departments in the organization, and they are systems that combine information technology (IT), computer science (CS) and management, and thus we have technological computer systems that work to help organizations complete their work, organize and facilitate its ability to deal with data and thus the possibility of making more correct, appropriate and organized decisions. From the perspective of Cummings et al. (2017), MIS is defined as automated systems aimed at helping managers and providing service to them by organizing work related to one of the departments and accomplishing many administrative tasks, most of which are office work such as organizing meetings and completing accounting tasks by relying on the use of technology in administrative operations. According to Weedmark (2019), the importance of MIS lies in its ability to overcome many negatives resulting from human work, such as lack of organization, neglect, inaccuracy, and commitment to time, and it also contributes to organizing work that would cause boredom and routine for individuals, which would contribute to reducing levels of incentives in place and thus a low level of performance affecting the output of the organization. On the other hand, Pozdniakov et al. (2018) referred to the adoption of management information systems that help reduce the burden on large organizations due to the huge volume of data that is received continuously, thus improving the level of competitiveness of the organization and its ability to adapt to the work environment.

\subsection{Components of MIS}

As it was presented by Kolobova et al. (2019); Abu Amuna et al. (2017) and Jeddi et al. (2020), MIS is not a system that is driven by itself, it is a system that is based on a group of components that includes:

- $\quad$ Devices: it includes all computers, laptops and physical tools that are designed to be used within the MIS framework.

- Programs: this component includes all system and application programs that an organization works on.

- $\quad$ Processes: it includes describing and arranging the set of steps and specific instructions to accomplish all computer operations, and it is also sometimes called a system path map.

- Data: It is the stored data that describe all the processes and current events in the organization with all the important details of its activities in the form of files. The data can be store by using the manual system or computerized, and the function of the information system is to convert this data into information.

- $\quad$ People: They are the individuals who operate and control other components, who are specialized and able to operate and manage information systems.

\subsection{MIS in Marketing Field}

Song et al. (2018) believe that MIS achieve specific goals by collecting data that the organization receives and processing it into information, and then reaching outputs and feedback. These processes according to Ashmarina and Zotova (2016) are somewhat like their existence as a control tool for each of the inputs, outputs, and feedback by not exceeding the limits of the system and taking data from the internal and external environments, strengths and identifying weaknesses and addressing them by relying on accuracy, comprehensiveness, and appropriateness. Zheng (2016) indicated that the marketing effect of MIS stems from the ability of these systems to organize and process data and present them in the form of reports to the management, which helps in taking an approach decision based on information that is identical to reality and appropriate to the nature of the studied market. While Martell (2018) argued that MIS is one of the very important systems in the marketing environment through its processing of data and the ability to provide information in a timely and appropriate situation, which made it have a great influence in the science of marketing, especially the electronic. Also, Paraforos et al. (2016) emphasized the importance of MIS in providing information processed from its origin as data, in addition to dealing professionally with various administrative levels depending on the reports it issues, as it provides a complete evaluation of the various marketing 
activities and ensuring that there are no potential deviations in it. Authors pointed out the role of MIS in the field of marketing as one of the most important ways that would help predict the future of electronic marketing campaigns and keep abreast of recent developments that would serve the marketing department in the organization.

\subsection{Methods}

Reaching the main aim of current study was done through adopting quantitative approach through utilizing the numerical data that stems from SPSS. To ease the process of application; a self-administered questionnaire was uploaded online - for COVID 19 reasons - and (150) individuals from different Jordanian telecommunications organizations responded to it. The questionnaire was built in two sections; the first took into perspective demographics of respondents, while the other section contained statements related to components of MIS (Devices ,Programs ,Processes, Data and People). The questionnaire was built on Likert 5 scale and was screened and processed using SPSS. After the application process, researcher was able to retrieve (131) properly filled questionnaires which was seen as a statistically accepted ratio of $(87.3 \%)$. Cronbach Alpha was used to test the reliability of the questionnaire, it was found that the alpha value equal to 0.935 which was good because it is greater than the accepted percent 0.60 .

\section{Analysis and Discussion}

\subsection{Demographic Results}

Analysis of respondents' demographics were illustrated in table 1 below, it appeared that most respondents was males forming $67.9 \%$ of the total sample compared to females who only represented $32.1 \%$ of total sample. As for age range, majority of individuals who responded to questionnaire was within age range of 30-40 years old forming $42.7 \%$ of total sample who held BA degree as an educational level of $87 \%$ and an experience of more 5-10 years in the field forming $37.4 \%$ of total sample.
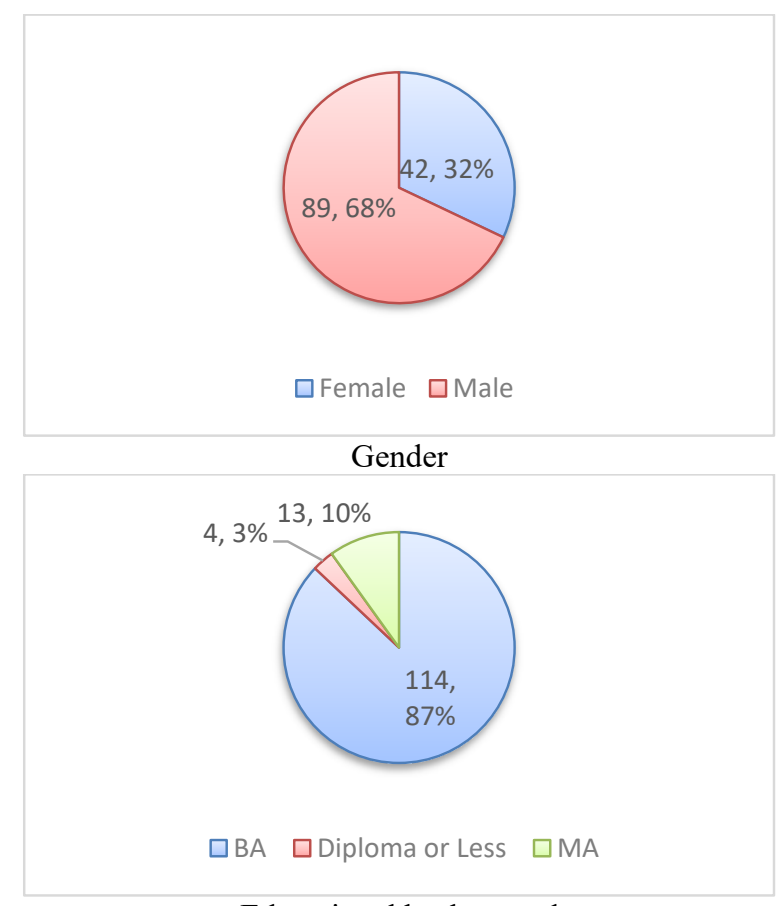

Educational background

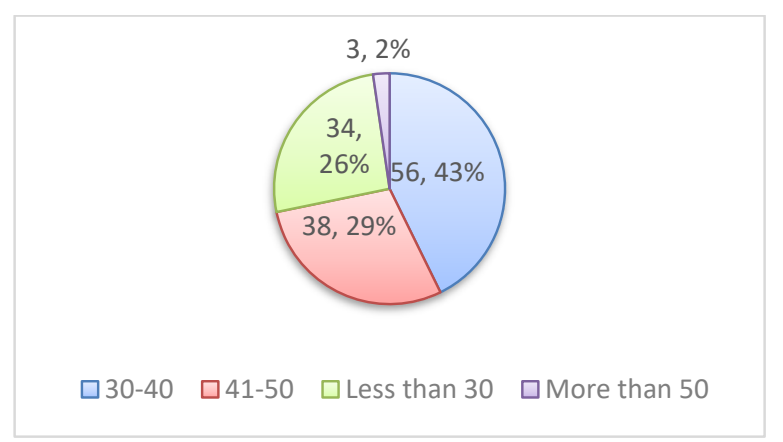

Age

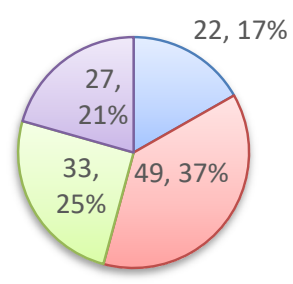

$\square$ Less than $5 \quad \square$ 10-May $\square 15$-Nov $\square 16$

Experience

Fig. 2. Personal characteristics of the participants

\subsection{Questionnaire Analysis}

Attitudes of respondents towards questionnaires were screened and analyzed utilizing SPSS. Table 2 presented such attitudes according to each statement presented.

It appeared through table 2 in the appendix that respondents had a positive attitude towards statements of questionnaire as all of them scored higher than mean of scale 3.00. The most positively received statement was articulated "Computers, printers and devices are all maintained on regular bases" scoring a mean of (4.47/5.00), while the least positively received statement scored a mean of (3.51/5.00) and was articulated "Management agrees on best practices to achieve goals and milestone".

Table 1 presents attitudes to respondents towards variables of study. It appeared that all respondents had positive attitudes towards the presented variables as all of them scored higher than the mean of scale which were seen as a good indicator. As 
it was shown in the table, process appeared to have the highest attitude compared to other variables of MIS scoring a mean of (3.98/5.00) which agreed with a high mean scored by e-marketing strategies of (4.07/500) referring to a good statistical indication.

Table 1

The summary of some basic statistics

\begin{tabular}{|c|c|c|c|c|c|}
\hline & $\mathrm{N}$ & Minimum & Maximum & Mean & Std. Deviation \\
\hline Devices & 131 & 1.86 & 5.00 & 3.9695 & .64402 \\
\hline Programs & 131 & 2.00 & 5.00 & 3.9603 & .74933 \\
\hline Processes & 131 & 1.80 & 5.00 & $\underline{3.9832}$ & .67256 \\
\hline$\overline{\text { Data }}$ & 131 & 2.00 & 5.00 & $\overline{3.9267}$ & .68127 \\
\hline People & 131 & 2.00 & 5.00 & 4.1344 & .65888 \\
\hline E-Marketing strategies & 131 & 1.45 & 5.00 & $\underline{4.0715}$ & .58830 \\
\hline
\end{tabular}

\subsection{Hypotheses Testing}

Hypotheses of study were testing utilizing multiple regression for the main hypothesis and simple regression for the subhypotheses which stemmed from MIS dimensions. As it was shown in tables below, all hypotheses were accepted and there appeared to be an influence of MIS dimensions on e-marketing strategies scoring a variance of (82.7\%) with the other dependent variables. This meant that the main hypothesis was accepted as it is shown in Table 2 . In the table, it can be seen that $\mathrm{F}$ value $=119.780$ was significant at 0.05 level which gave an indication that MIS components positively influence e-marketing strategies. With an $\mathrm{R}=0.91$ reflected a high level of correlation between the independent variables and dependent variable, it explained $82.7 \%$ of the variance in the dependent variable.

\section{H: MIS components positively influence e-marketing strategies.}

Table 2

The results of testing the main hypothesis

\begin{tabular}{|c|c|c|c|c|c|c|c|c|c|}
\hline \multirow[b]{2}{*}{ Mod } & & \multicolumn{2}{|c|}{ Unstandardized Coefficients } & \multirow{2}{*}{$\frac{\text { Standardized Coefficients }}{\text { Beta }}$} & \multirow[b]{2}{*}{$\mathrm{t}$} & \multirow[b]{2}{*}{ Sig. } & \multirow[b]{2}{*}{$\mathrm{R}$} & \multirow[b]{2}{*}{ R Square } & \multirow[b]{2}{*}{$\mathrm{F}$} \\
\hline & & $\mathrm{B}$ & Std. Error & & & & & & \\
\hline \multirow[t]{6}{*}{1} & (Constant) & .557 & .153 & & 3.637 & .000 & \multirow{6}{*}{0.91} & \multirow{6}{*}{0.827} & \multirow{6}{*}{119.78} \\
\hline & Devices & .141 & .079 & .154 & 1.781 & .077 & & & \\
\hline & Programs & -.033 & .079 & -.042 & -.424 & .672 & & & \\
\hline & Processes & -.011 & .068 & -.012 & -.159 & .874 & & & \\
\hline & Data & .299 & .072 & .347 & 4.178 & .000 & & & \\
\hline & People & .473 & .060 & .530 & 7.858 & .000 & & & \\
\hline
\end{tabular}

Table 3 presents the testing of $1^{\text {st }}$ sub-hypothesis articulated "Devices positively influence e-marketing strategies", simple regression test was used to show that $\mathrm{T}$ value $=15.312$ was statistically significant at level $0.05, \mathrm{R}$ value $=0.803$ referring to the strength of the relationship between the independent variable and the dependent variable and confirming that Devices positively influence e-marketing strategies.

Table 3

The results of testing the first sub-hypothesis

\begin{tabular}{|c|c|c|c|c|c|c|c|c|c|}
\hline \multirow[b]{2}{*}{ Model } & & \multicolumn{2}{|c|}{ Unstandardized Coefficients } & \multirow{2}{*}{$\frac{\text { Standardized Coefficients }}{\text { Beta }}$} & \multirow[b]{2}{*}{$\mathrm{t}$} & \multirow[b]{2}{*}{ Sig. } & \multirow[b]{2}{*}{$\mathrm{R}$} & \multirow[b]{2}{*}{ R Square } & \multirow[b]{2}{*}{$\mathrm{F}$} \\
\hline & & $\mathrm{B}$ & Std. Error & & & & & & \\
\hline 1 & (Constant) & 1.159 & .193 & & 6.017 & .000 & 0.803 & 0.645 & 234.456 \\
\hline & Devices & .734 & .048 & .803 & 15.312 & .000 & & & \\
\hline
\end{tabular}

As for the $2^{\text {nd }}$ sub-hypothesis, Table 4 below explained - depending on simple regression - that "Programs positively influence e-marketing strategies", this acceptance of the hypothesis was decided based on T value $=15.328$ was statistically significant at level $0.05, \mathrm{R}$ value $=0.803$ referring to the strength of the relationship between the independent variable and the dependent variable and confirming that Programs positively influence e-marketing strategies.

Table 4

The results of testing the second sub-hypothesis

\begin{tabular}{|c|c|c|c|c|c|c|c|c|c|}
\hline \multirow[b]{2}{*}{ Model } & & \multicolumn{2}{|c|}{ Unstandardized Coefficients } & \multirow{2}{*}{$\frac{\text { Standardized Coefficients }}{\text { Beta }}$} & \multirow[b]{2}{*}{$\mathrm{t}$} & \multirow[b]{2}{*}{ Sig. } & \multirow[b]{2}{*}{$\mathrm{R}$} & \multirow[b]{2}{*}{ R Square } & \multirow[b]{2}{*}{$\mathrm{F}$} \\
\hline & & $\mathrm{B}$ & Std. Error & & & & & & \\
\hline 1 & (Constant) & 1.573 & .166 & & 9.486 & .000 & 0.803 & 0.646 & 234.952 \\
\hline & Programs & .631 & .041 & .803 & 15.328 & .000 & & & \\
\hline
\end{tabular}


In the $3^{\text {rd }}$ hypothesis, also simple regression as used and it appeared that the hypothesis was accepted and "Processes positively influence e-marketing strategies" through the T value $=13.712$ which was statistically significant at level $0.05, \mathrm{R}$ value $=0.77$ referring to the strength of the relationship between the independent variable and the dependent variable.

Table 5

The results of testing the third sub-hypothesis

\begin{tabular}{|c|c|c|c|c|c|c|c|c|c|}
\hline \multirow[b]{2}{*}{ Model } & & \multicolumn{2}{|c|}{ Unstandardized Coefficients } & \multirow{2}{*}{$\begin{array}{c}\text { Standardized Coefficients } \\
\text { Beta }\end{array}$} & \multirow[b]{2}{*}{$\mathrm{t}$} & \multirow[b]{2}{*}{ Sig. } & \multirow[b]{2}{*}{$\mathrm{R}$} & \multirow[b]{2}{*}{ R Square } & \multirow[b]{2}{*}{$\mathrm{F}$} \\
\hline & & $\mathrm{B}$ & Std. Error & & & & & & \\
\hline 1 & (Constant) & 1.388 & .198 & & 6.996 & .000 & 0.77 & 0.593 & 188.018 \\
\hline & Progress & .674 & .049 & .770 & 13.712 & .000 & & & \\
\hline
\end{tabular}

The $4^{\text {th }}$ sub-hypothesis was also accepted, and it appeared that "Data positively influence e-marketing strategies" since simple regression managed to indicate a $\mathrm{T}$ value $=16.484$ as statistically significant at level $0.05, \mathrm{R}$ value $=0.823$ referring to the strength of the relationship between the independent variable and the dependent variable, then, it can be said that Data positively influence e-marketing strategies.

Table 6

The results of testing the fourth sub-hypothesis

\begin{tabular}{|c|c|c|c|c|c|c|c|c|c|}
\hline \multirow[b]{2}{*}{ Model } & & \multicolumn{2}{|c|}{ Unstandardized Coefficients } & \multirow{2}{*}{$\begin{array}{c}\text { Standardized Coefficients } \\
\text { Beta }\end{array}$} & \multirow[b]{2}{*}{$\mathrm{t}$} & \multirow[b]{2}{*}{ Sig. } & \multirow[b]{2}{*}{$\mathrm{R}$} & \multirow[b]{2}{*}{ R Square } & \multirow[b]{2}{*}{$\mathrm{F}$} \\
\hline & & $\mathrm{B}$ & Std. Error & & & & & & \\
\hline 1 & (Constant) & (Constant) & 1.279 & .172 & & 7.442 & .000 & 0.823 & 0.678 \\
\hline & Data & Data & .711 & .043 & .823 & 16.484 & .000 & & \\
\hline
\end{tabular}

At last, the $5^{\text {th }}$ sub-hypothesis was articulated "People positively influence e-marketing strategies". The hypothesis was tested depending on simple regression as it showed that $T$ value $=20.202$ was statistically significant at level $0.05, R$ value $=0.872$ referring to the strength of the relationship between the independent variable and the dependent variable and confirming that People positively influence e-marketing strategies.

Table 7

The results of testing the fifth sub-hypothesis

\begin{tabular}{|c|c|c|c|c|c|c|c|c|c|}
\hline \multirow[b]{2}{*}{ Model } & & \multicolumn{2}{|c|}{ Unstandardized Coefficients } & \multirow{2}{*}{$\frac{\text { Standardized Coefficients }}{\text { Beta }}$} & \multirow[b]{2}{*}{$\mathrm{t}$} & \multirow[b]{2}{*}{ Sig. } & \multirow[b]{2}{*}{$\mathrm{R}$} & \multirow[b]{2}{*}{ R Square } & \multirow[b]{2}{*}{$\mathrm{F}$} \\
\hline & & $\mathrm{B}$ & Std. Error & & & & & & \\
\hline 1 & (Constant) & .854 & .161 & & 5.293 & .000 & .872 & .760 & 408.111 \\
\hline & People & .778 & .039 & .872 & 20.202 & .000 & & & \\
\hline
\end{tabular}

\section{Discussion}

Current study aimed at examining how influential MIS components are on the efficiency of e-marketing strategies within telecommunication organizations in Jordan. A non-probability sample was retrieved from Jordanian telecommunication organizations, (131) respondents participated in a self-administered questionnaire. Results of analyzing gathered data indicated the following:

- $\quad$ Respondents had a high level of awareness regarding MIS and its components given their positive attitudes towards the questionnaire.

- $\quad$ Main hypothesis "MIS components positively influence e-marketing strategies" was accepted with a high variance of $82.7 \%$ indicating that MIS components do have the ability to increase the efficiency of e-marketing strategies.

- $\quad$ All components of MIS - (Devices ,Programs ,Processes, Data and People) - appeared to be influential on the efficiency of e-marketing strategies. The most influential variable of all was (people) scoring an $\mathrm{R}$ value of .872 and explaining $76 \%$ of the relationship between variables.

Study was able to show that adopting a well-built base of MIS components can help in increasing the positive outcomes of marketing strategies among organizations. The influence increases in the case of e-marketing as it depends on individuals, devices and programs that are suitable and user friendly to be employed on the internet. What gave the impact of MIS on emarketing strategies is its enjoyment of a modern electronic character through the combination of information technology, computer science and management, and this is consistent with some studies (Freihat, 2012; Albuquerque et al., 2018; QuesadaPineda et al., 2017; Vyas et al., 2014) on the impact of MIS on electronic practices in organizations, as it helps in solving problems and obstacles and dependence on the various applications in the collection of information, in addition to the possibility of permanent development and the fact that there is no certain modernization limit for such applications, but there is a permanent possibility of updating according to the capabilities of the organization of devices, users, programs and tools. 


\subsection{MIS Usage Can Enhance E-Marketing Strategies}

According to analysis, there appeared the effect of MIS components on marketing strategies and their focus - according to the results of the study - on (human resources). The intention here of human resources is the group of individuals or users who directly deal with MIS outputs in order to ensure obtaining the best appropriate and compatible outputs with reality.

The study was able to prove that MIS is one of the most important factors affecting the growth of businesses and organizations by clarifying its role in e-commerce and e-marketing through focusing on competencies and capabilities. This effect appeared through the ability of MIS to provide detailed operational reports in addition to processing data obtained and transformed into information that the organization can interpret and deal with, in order to make decisions related to the marketing work of various administrative levels. MIS provides various reports through their existence as (executive support systems) in order to facilitate the mechanism of dealing with data and various reports, which would help in making (non-routine) decisions and organizing long-term strategies in strategic planning. MIS appears again as (decision support systems), by employing the reports issued that will contribute to solving problems and facilitate decision-making that requires many measures.

In addition to that, MIS provides what is known as (Marketing and Sales Information System), which are the systems that collect, store, analyze and present e-marketing information to managerial levels based on their needs during regular periods, and the (Marketing and Sales Information System) contributes to understanding marketing needs and its most efficient methods, in addition to collecting data from internal sources in a continuous and ad-hoc manner, and working to conduct appropriate surveys for the market environment, as well as conducting marketing research.

\subsection{Components of MIS are Influential on E-Marketing Strategies}

The study indicated through the analysis that all the components of MIS had an impact on the effectiveness of e-marketing strategies, but it appeared that the highest of these effects were from people or human resources. The importance of human resources lies in the fact that they are the element that operates, directs and deals with these systems, and they must have sufficient experience in order to deal with these systems in a manner capable of demonstrating their potential and their impact on the organization as a whole. This result rhymed with what came along with Kolobova et al (2019) and Abu Amuna et al (2017) who stressed on the importance of human resources in dealing with, managing, operating and using MIS applications.

\section{Conclusion}

Due to the rapid development of information systems witnessed in current time, information and its modern systems are considered a force for rational decision-making and building the formation of successful and effective strategies. This study came to shed light on the impact of management information systems on e-marketing strategies within Jordanian telecommunications companies. This goal stems from the reality of the importance of e-marketing in the organizations these days. Good and effective e-marketing can determine the competitiveness and viability of organizations in the local and global market. Current study demonstrated the importance of MIS in the field of e-marketing through the clear impact of MIS in the organization and management of information. The MIS is considered one of the most important resources within the organization for higher management and departments. The MIS with its components, with the presence of expertise and competencies, contributes to building marketing strategies, organizing and modifying them in proportion to market fluctuations and competitiveness in it.

Based on the results and the discussion presented earlier, current study recommends the following:

- $\quad$ Concentrating on human resources with $\underline{\boldsymbol{S T E M}}$ skills, namely science, technology, engineering, and mathematics to ensure the best outcomes of MIS.

- $\quad$ Monitoring the efficiency of electronic devices such as computers and printers, and fixing faults periodically.

\section{References}

Abu Amuna, Y. M., Al Shobaki, M. J., \& Abu-Naser, S. S. (2017). The Role of Knowledge-Based Computerized Management Information Systems in the Administrative Decision-Making Process.

Aditya, B. (2014). Web Based Marketing Management Information Systems (Study at CV. Karya Gaja Mandiri Surabaya) (Doctoral dissertation, Universitas Brawijaya).

Albuquerque, H., Costa, C., \& Martins, F. (2018). The use of geographical information systems for tourism marketing purposes in Aveiro region (Portugal). Tourism Management Perspectives, 26, 172-178.

Ali, M. M. (2019). Impact of Management Information Systems (MIS) on Decision Making. Global Disclosure of Economics and Business, 8(2), 83-90.

Altmann, P., \& Linder, M. (2019). Managing emerging (Mis) alignments in data-driven servitization. Research-Technology Management, 62(4), 37-45.

Ashmarina, S., \& Zotova, A. (2016). The system of marketing information management: development, assessment, improvement. Економічний часопис-XXI, 160, 51-56. 
Chiang, R. H., Grover, V., Liang, T. P., \& Zhang, D. (2018). Strategic value of big data and business analytics, Journal of Management Information Systems, 35(2), 383-387

Cummings, S., Bridgman, T., Hassard, J., \& Rowlinson, M. (2017). A new history of management. Cambridge University Press.

Freihat, S. M. S. (2012). The role of marketing information system in marketing decision-making in Jordanian shareholding medicines production companies. International Journal of Research and Reviews in Applied Sciences, 11(2).

Goel, A., \& Tiwari, M. (2020). Intelligent MIS for High-Quality Marketing Decisions. In Transforming Management Using Artificial Intelligence Techniques (pp. 73-88). CRC Press.

Jeddi, F. R., Nabovati, E., Bigham, R., \& Khajouei, R. (2020). Usability evaluation of a comprehensive national health information system: Relationship of quality components to users' characteristics. International Journal of Medical Informatics, 133, 104026.

Kolobova, E., Shigina, N., Remontov, A., \& Chigireva, I. (2019, September). Modeling of Automated Information System Components for Management of Teaching Materials of Discipline. In 2019 XXI International Conference Complex Systems: Control and Modeling Problems (CSCMP) (pp. 754-759). IEEE.

Lin, A. J., Hsu, C. L., \& Chiang, C. H. (2016). Bibliometric study of electronic commerce research in information systems \& MIS journals. Scientometrics, 109(3), 1455-1476.

Lui, R. W., \& Au, C. H. (2017, December). Designing simulation games for information systems education-A case study in teaching for digital marketing. In 2017 IEEE 6th International Conference on Teaching, Assessment, and Learning for Engineering (TALE) (pp. 290-295). IEEE.

Martell, D. A. (2018). Marketing Information and New Technology. In Management Information Systems: The Technology Challenge (pp. 161-181). Routledge.

Meeßen, S. M., Thielsch, M. T., \& Hertel, G. (2019). Trust in Management Information Systems (MIS). Zeitschrift für Arbeits-und Organisationspsychologie $A \& O$.

Paraforos, D. S., Vassiliadis, V., Kortenbruck, D., Stamkopoulos, K., Ziogas, V., Sapounas, A. A., \& Griepentrog, H. W. (2016). A farm management information system using future internet technologies. IFAC-PapersOnLine, 49(16), 324329.

Pozdniakov, S., Kuzmin, O., Kiiko, V., \& Korenets, Y. (2018). Definition of the role of business modeling in the building of a management information system.

Quesada-Pineda, H., Brenes-Bastos, M., \& Smith, R. (2017). Assessing geographic information systems use in marketing applications for the wood products industry. BioProducts Business, 14-22.

Singh, J. (2017). Management Information Systems (MIS) in Cloud Computing: A Review. International Journal of Business Analytics (IJBAN), 4(3), 54-70.

Song, J. O., Cho, J. H., Choi, D. J., \& Yoo, J. S. (2018). A management information system for beauty business based on social influencer marketing using hot topic. In Proceedings of the Korean Society of Computer Information Conference (pp. 207-210). Korean Society of Computer Information.

Trivedi, A., \& Verma, D. (2018). Review on Management Information Systems (MIS) Control and its Role in Strategic Decision Making, International Journal of Technology Research and Management, 5(3).

Vyas, V., Vyas, S., \& Devra, N. (2014). Application of Management Information System in Marketing Management. International Journal of Information \& Computation Technology, 4(17), 1825-1829.

Weedmark, D. (2019). The History of Management Information Systems. Retried from: https://bizfluent. com/about-5444925history-management-information-systems. html.

Yordanova, Z. (2018). Management Information Systems (MIS) Boost Organizational Innovation Competencies. In Proceedings of International Conference on Application of Information and Communication Technology and Statistics in Economy and Education (ICAICTSEE) (pp. 217-224). International Conference on Application of Information and Communication Technology and Statistics and Economy and Education (ICAICTSEE).

Zheng, Y. (2016, April). Study on the Application of Power Marketing Inspection in Marketing Management Information System. In 6th International Conference on Electronic, Mechanical, Information and Management Society. Atlantis Press. 
Appendix

Table A1. Descriptive Statistics

\begin{tabular}{|c|c|c|c|c|c|}
\hline & $\mathrm{N}$ & Minimum & Maximum & Mean & Std. Deviation \\
\hline \multicolumn{6}{|l|}{$\begin{array}{l}\text { MIS Components } \\
\text { Devices }\end{array}$} \\
\hline Computers, printers and devices are all maintained on regular bases & 131 & 2 & 5 & 4.47 & .737 \\
\hline Management always makes sure that all devices are up to date & 131 & 2 & 5 & 4.16 & .721 \\
\hline Devices are updated in regular bases for the sake of accuracy & 131 & 1 & 5 & 3.83 & .852 \\
\hline Devices are friendly user & 131 & 2 & 5 & 3.81 & .833 \\
\hline Devices are distributed as according to each department's needs & 131 & 1 & 5 & 3.66 & .910 \\
\hline Hardware provides the computing power for processing data & 131 & 1 & 5 & 3.86 & .901 \\
\hline $\begin{array}{l}\text { Devices provide networking and printing capabilities } \\
\text { Programs }\end{array}$ & 131 & 2 & 5 & 4.00 & .734 \\
\hline Programs are chosen to fit the needs of the department & 131 & 2 & 5 & 3.92 & .724 \\
\hline Users have full access to programs as according to their needs & 131 & 2 & 5 & 3.89 & .829 \\
\hline All data are preserved on well-built programs & 131 & 1 & 5 & 4.11 & .816 \\
\hline Operating systems and programs match the needs of each department & 131 & 2 & 5 & 3.98 & .944 \\
\hline $\begin{array}{l}\text { There are specialized programs for department like accounting and quality as- } \\
\text { Processes }\end{array}$ & 131 & 2 & 5 & 3.91 & .940 \\
\hline Management agrees on best practices to achieve goals and milestone & 131 & 1 & 5 & 3.51 & 1.119 \\
\hline Processes agreed on can guide people to work efficiently & 131 & 2 & 5 & 4.17 & .670 \\
\hline Processes are developed by people who are professional and consultants & 131 & 2 & 5 & 3.98 & .784 \\
\hline All processes can achieve the main aim of the adopted plan & 131 & 2 & 5 & 4.16 & .711 \\
\hline $\begin{array}{l}\text { Processes suit the internal and external environment of the organization } \\
\text { Data }\end{array}$ & 131 & 1 & 5 & 4.09 & .907 \\
\hline All business transactions are recorded precisely & 131 & 1 & 5 & 3.82 & .988 \\
\hline Data collected from activities are monitored by well-built programs & 131 & 1 & 5 & 3.65 & .919 \\
\hline Data are monitored in terms of accuracy automatically and manually & 131 & 1 & 5 & 3.80 & .798 \\
\hline Data are stored in the cloud and on manual records for emergencies & 131 & 2 & 5 & 4.22 & .683 \\
\hline $\begin{array}{l}\text { Marketing data are monitored and processed in an effective way } \\
\text { People }\end{array}$ & 131 & 2 & 5 & 4.14 & .752 \\
\hline Day to day business transactions are recorded in an organized way & 131 & 2 & 5 & 4.16 & .812 \\
\hline All users are qualified and professional & 131 & 1 & 5 & 3.96 & .872 \\
\hline Users get constant training and workshops to increase their ability to manage & 131 & 2 & 5 & 3.95 & .660 \\
\hline IT department makes sure that all staff are supported with the needed help & 131 & 2 & 5 & 4.29 & .707 \\
\hline $\begin{array}{l}\text { IT department makes sure that all devices are working properly } \\
\text { E-marketing strategies }\end{array}$ & 131 & 2 & 5 & 4.31 & .703 \\
\hline e-marketing depends on continuous systems & 131 & 2 & 5 & 4.10 & .689 \\
\hline Networking and social media are preserved for the benefit of e-marketing & 131 & 2 & 5 & 4.21 & .731 \\
\hline Adopted MIS supports marketing department with the suitable marketing in- & 131 & 2 & 5 & 4.15 & .638 \\
\hline Marketing strategies can be applied through information systems by all levels & 131 & 2 & 5 & 4.23 & .651 \\
\hline MISs collected marketing data from internal and external sources & 131 & 1 & 5 & 3.82 & .827 \\
\hline MISs in marketing provides the management with suitable information for & 131 & 1 & 5 & 4.24 & .689 \\
\hline The organization makes sure that MISs collects data that are suitable for mar- & 131 & 1 & 5 & 4.01 & .770 \\
\hline The marketing environment is monitored by well-built information systems & 131 & 1 & 5 & 4.23 & .873 \\
\hline Information systems are able to collect marketing data from competitors & 131 & 1 & 5 & 3.90 & .812 \\
\hline Market research is attainable through MISs & 131 & 1 & 5 & 3.86 & .752 \\
\hline MISs are able to aid marketing decision within higher management & 131 & 1 & 5 & 4.04 & .717 \\
\hline
\end{tabular}




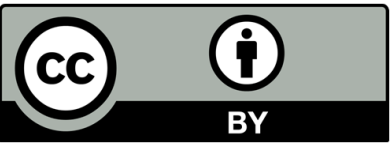

(C) 2022 by the authors; licensee Growing Science, Canada. This is an open access article distributed under the terms and conditions of the Creative Commons Attribution (CC-BY) license (http://creativecommons.org/licenses/by/4.0/). 